\title{
EVALUASI KINERJA TURBIN GAS ABB GT 13-E1 DI PT. INDONESIA POWER, UBP PRIOK
}

Kartono, Sekti Kunthi dan Tina Mulya Gantina

\author{
Jurusan Teknik Konversi Energi - Politeknik Negeri Bandung \\ Email: kartonopolban@yahoo.co.id; esekti@yahoo.com
}

\begin{abstract}
Abstrak
Turbin Gas merupakan salah satu komponen terpenting dalam sistem PLTG dan PLTGU, maka dari itu turbin gas memerlukan perhatian lebih sehingga perlu dilakukan evaluasi kinerjanya. Prinsip kerja turbin gas adalah mengkonversi energi kimia yang terkandung di dalam bahan bakar menjadi gas panas, yang selanjutnya tekanan gas panas tersebut dipakai untuk menggerakan poros turbin untuk menghasilkan listrik. Salah satu gambaran yang dapat menunjukan kinerja turbin gas adalah efisiensi. Berdasarkan hasil pengujian efisiensi dengan menggunakan metode tidak langsung pada turbin gas $A B B$ GT 13-E1 di PT Indonesia Power UBP Priok, diperoleh data bahwa sudah terjadi penurunan di kompresor, ruang bakar, dan turbin. Penurunan efisiensi di kompresor adalah sebesar 6,5-7,3\%.; di ruang bakar terjadi penurunan efisiensi sebesar 16,8-19,1\% dan di turbin terjadi penurunan efisiensi sebesar 15,9-18,18\%. Dengan demikian penurunan efisiensi thermal di turbin gas adalah sebesar 15$21 \%$.
\end{abstract}

\section{PENDAHULUAN}

\section{Latar Belakang}

Pemanfaatan listrik sebagai salah satu sumber energi dewasa ini sudah sangat vital, baik di kalangan industri maupun rumah tangga. Lambat tahun pemanfaatan listrik diharapkan dapat memenuhi semua kebutuhan manusia. Beberapa alternatif mesin konversi energi sebagai alat penggerak generator terus dikembangkan salah satunya adalah turbin gas.

Turbin gas merupakan salah satu komponen dari sistem PLTG dan PLTGU, Turbin gas sendiri merupakan komponen yang perlu perhatian sangat lebih dibanding dengan komponen pembangkit listrik lainnya, komponen utama dari turbin gas sendiri yaitu : compressor (Kompresor), Combustion area (Ruang bakar), turbin. Proses singkat turbin gas sendiri yaitu, udara dikompressi di dalam kompresor dan selanjutnya udara bertekanan dialirkan ke dalam ruang bakar bercampur dengan bahan bakar, sehingga terjadi proses pembakaran. Gas hasil pembakaran berekspansi di dalam turbin gas sehingga dihasilkan tenaga mekanik poros, poros turbin gas dikopel dengan generator listrik sehingga dihasilkan tenaga listrik. Dari proses tersebut terlihat komponen turbin gas satu sama lain saling ketergantungan, maka dari itu jika salah salah satu komponen turbin gas tersebut mengalami kerusakan atau degradas $i$ (penurunan kinerja), hal ini akan berpengaruh pada produksi listrik (output) yang dihasilkan maupun bahan bakar (input) yang dikonsumsi. Kedua akibat ini akan merugikän perusahaan, dan masyarakat yang mengkonsumsi lstrik.

Kinerja alat yang baik akan menghasilkan penghematan dan pada akhirnya akan memperkecil harga penggunaan energi yang dibutuhkan. Dengan hematnya penggunaan energi maka kita dapat menekan ongkos operasi, sehingga produk yang dihasilkan dapat dilepaskan ke pasaran dengan harga yang lebih murah. Dengan diketahuinya pemakaian atau penggunaan energi, Penulis dalam penulisan tugas akhir ini akan melakukan perhitungan kinerja turbin gas secara tidak langsung, guna mengevaluasi dan mengetahui apakah komponenkomponen utama turbin gas di PT Indonesia Power UBP Priok ini perlu dilakukan perbaikan atau sudah dalam kondisi cukup optimal.

\section{DasarTeori}

Kerugian dari turbin gas adalah suhu yang keluar dari gas buang cukup tinggi yaitu di atas $500^{\circ} \mathrm{C}$, akan tetapi tekanan yang dihasilkan oleh turbin gas sangat rendah sehingga gas buang ini tidak dapat dimanfaatkan menjadi fluida kerja, sedangkan kerugian dari turbin uap adalah temperatur uap masuk turbin rata-rata lebih rendah dibandingkan dengan turbin gas, dengan demikian sangatlah ideal bila kedua jenis turbin ini dikombinasikan atau yang dikenal dengan Combined Cycle. Maka dari itu digunakanlah HRSG sebagai jalan keluar untuk memanfaatkan 
gas buang dari turbin gas yang masih memiliki energi yang relatif tinggi yang dapat dimanfaatkan sebagai sumber energ bagi siklus uap. Dengan demikian kedua siklus tersebut dapat digabung menjadi satu siklus yang terdiri dari turbin gas dan turbin uap yang masingmasing menggerakan generator dan menghasilkan listrik. Siklus gabungan ini disebut "siklus Combine Cycle". Keuntungan dari siklus combine cycle ini adalah:

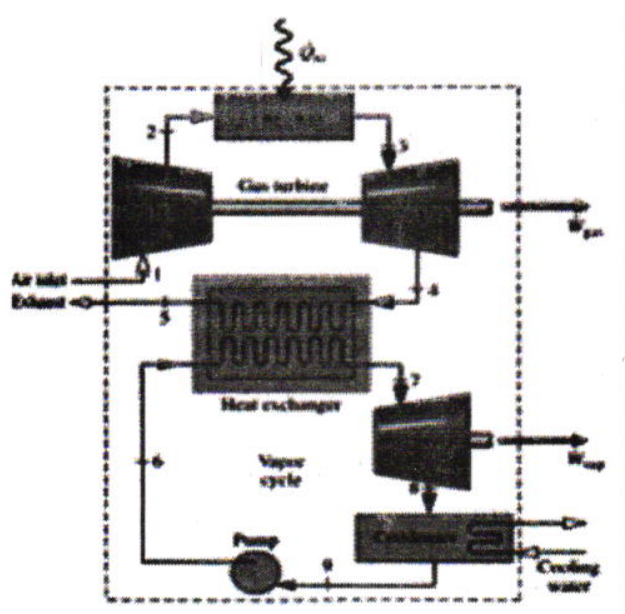

Gambar 1. Siklus Combine Cycle

1. Dapat menambah daya listrik dan dapat menghemat penggunaan bahan bakar, hal ini akan meningkatkan efisiensi termal sistem.

2. Waktu konstruksi yang cepat sehingga pada saat terjadi lonjakan permintaan tenaga listrik maka dapat dilakukan pembangunan PLTGU secara bertahap.

3. Dengan PLTGU maka biaya produksi listrik menjadi efisien. Tanpa perlu mengeluarkan biaya bahan bakar lagi, unit ini sanggup untuk menghasilkan listrik lagi. Nilai produksinya pun cukup besar. Daya maksimal yang bisa dihasilkan dari pemanfaatan gas buang ini bisa mencapai 60 $\%$ dari daya yang dihasilkan oleh turbin gas. Jadi permisalan, jika gas turbin menghasilkan listrik $100 \mathrm{MW}$, maka gas buang yang dimanfaatkan tadi bisa memproduksi listrik tambahan melalui turbin uap sebanyak $60 \mathrm{MW}$.

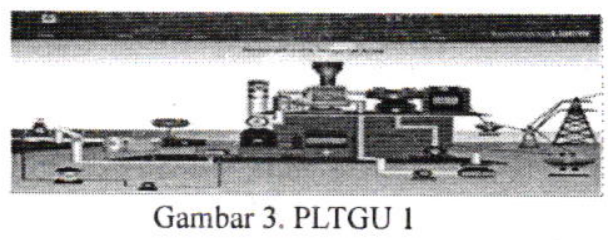

Udara dikompressi di dalam kompresor (C) dan selanjutnya udara bertekanan dialirkan ke dalam ruang bakar (CC) dan bercampur dengan bahan bakar sehingga terjadi proses pembakaran. Gas hasil pembakaran berekspansi di dalam turbin gas (GT) sehingga dihasilkan tenaga mekanik poros. Poros turbin gas dikopel dengan generator listrik sehingga dihasilkan tenaga listrik. Gas bekas dari turbin gas dialirkan kedalam Heat Recovery Steam Generator (HRSG) untuk memanaskan air menjadi uap. Selanjutnya uap berekspansi di dalam turbin uap sehingga dihasilkan tenaga mekanik poros. Poros turbin uap dikopel dengan generator listrik sehingga dihasilkan tenaga listrik. Uap bekas dari turbin uap dikondensasikan di dalam kondensor selanjutnya dipompakan kembali ke dalam HRSG.

\section{Siklus Turbin Gas}

Siklus Bryton adalah siklus daya temodinamika ideal untuk turbin gas, siklus ini terdiri dari proses kompresi isentropik yang diakhiri dengan proses pelepasan panas pada tekanan yang konstan. Siklus ini terdiri dari dua proses isobar yang terjadi di ruang bakar dan proses pembuangan gas bekas dan dua proses isentropis yang terjadi di kompresor dan ekspansi gas pada turbin.

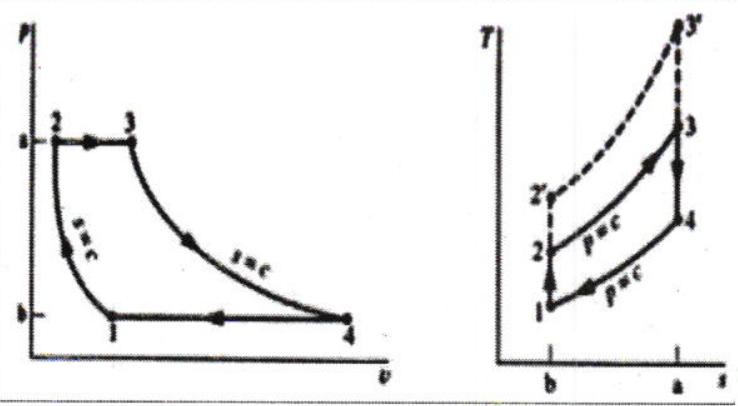

Gambar 2. Siklus bryton

Proses 1-2 : adalah proses kompresi isentropic (tidak ada penambahan kalor), udara lingkungan sebagai fluida kerja dengan tekanan atmosfir pada titik 1 dihisap oleh kompresor lalu ditekan ke titik 2, pada titik ini suhu dan tekanan naik sekitar $603 \mathrm{~K} / 12$ bar pada titik 2 saat ini bahan bakar diinjeksikan dan terjadi proses pembakaran

Kompresi isentropis di dalam kompresor

$$
I_{2}=T_{1} \operatorname{rp}^{\gamma} \gamma^{1}\left(r p=\frac{p 2}{\nu_{1}}\right)
$$

$\gamma=$ perbandingan panas spesifik pada tekanan konstan dan panas spesifik pada volume konstan untuk udara 1,4 .

Proses 2-3 : adalah proses penambahan panas dengan tekanan tetap di dalam ruang bakar, titik 3 adalah titik meninggalkan ruang bakar suhu rata-rata GT13E Priok sekitar $1343 \mathrm{~K}$. 


$$
\mathrm{Q}_{\mathrm{i}}=\mathrm{cp} \times\left(\mathrm{T}_{3}-\mathrm{T}_{2}\right)
$$

Proses 3-4 : adalah proses ekspansi isentropic didalam turbin, energi dari gas hasil pembakaran diubah menjadi kerja, suhu pada titik 4 sekitar $802^{\circ} \mathrm{K}$ di buang ke lingkungan pada siklus terbuka sedangkan pada waktu siklus ganda dimanfaatkan oleh HRSG.

$$
T_{4}=T_{3}\left[\frac{1}{r p r^{r-1}}\right]
$$

Proses 4-1 : adalah proses pembuangan panas pada tekanan konstan ke udara, besarnya kalor yang dilepas dihitung dengan

$$
\text { QouT }=\mathrm{T}_{4}-\mathrm{T}_{1}
$$

Kerja spesifik siklus adalah selisih kerja yang dihasilkan turbin dengan kerja yang dibutuhkan kompresor tiap kg gas.

$$
\begin{aligned}
\mathrm{W}_{\mathrm{NET}} & =\mathrm{W}_{\mathrm{T}}-\mathrm{W}_{\mathrm{K}} \\
& =\left(\mathrm{h}^{3}-\mathrm{h}^{\prime}{ }^{\prime}\right)-\left(\mathrm{h}^{\prime}{ }^{\prime}-\mathrm{h} 1\right)
\end{aligned}
$$

Kalor spesifik adalah selisih antara kalor yang masuk dengan kalor yang keluar.

$$
\begin{aligned}
\mathrm{Q}_{\text {eff }} & =Q_{\text {IN }}-Q_{\text {OUT }} \\
& =(h 3-h 2)-(h 4-h 1)
\end{aligned}
$$

Efisiensi siklus merupakan perbandingan jumlah kalor yang efektif dengan kalor yang dimasukan ke sistem

$$
\begin{aligned}
& \eta \text { siklus }=\frac{\text { Wnetc }}{Q \text { in }} \\
& \frac{\left(\mathrm{h} 3-\mathrm{h} 2^{\prime}\right)-\left(\mathrm{h} 4^{\prime}-\mathrm{h} 1\right)}{\left(\mathrm{h} 3-\mathrm{h} 2^{\prime}\right)}
\end{aligned}
$$

\section{Komponen Utama Turbin Gas}

Gas-turbine engine adalah suatu alat yang memanfaatkan gas sebagai fluida untuk memutar turbin dengan pembakaran internal. Di dalam turbin gas energi kinetik dikonversikan menjadi energi mekanik melalui udara bertekanan yang memutar roda turbin sehingga menghasilkan daya. Sistem turbin gas yang paling sederhana terdiri dari tiga komponen yaitu kompresor, ruang bakar dan turbin gas.Turbin gas secara teori tidak begitu rumit untuk menjelaskannya. Terdapat 3 komponen atau bagian utama yaitu:

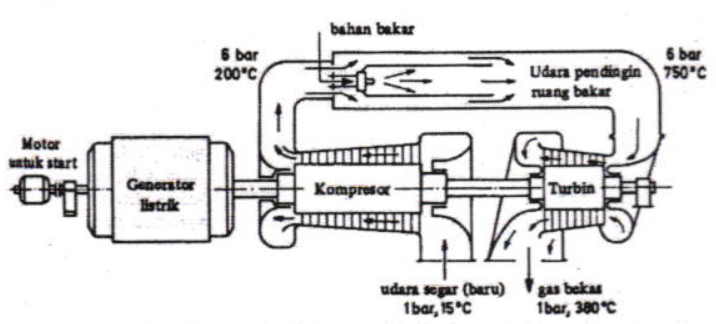

Gambar 4. Turbin Gas Industri 1

\section{Kompresor}

Kompresor utama adalah kompesor aksial yang berguna untuk memasok udara bertekanan ke dalam ruang bakar yang sesuai dengan kebutuhan. Kapasitas kompresor harus cukup besar karena pasokan udara lebih (excess air) untuk turbin gas dapat mencapai $350 \%$. Disamping untuk mendapatkan pembakaran yang sempurna, udara lebih ini digunakan untuk pendingin dan menurunkan suhu gas hasil pembakaran.

\section{Combustion area}

Combustion Chamber adalah ruangan tempat proses terjadinya pembakaran. Ada turbin gas yang mempunyai satu atau dua Combustion Chamber yang letaknya terpisah dari casing turbin, akan tetapi yang lebih banyak dijumpai adalah memiliki Combustion Chamber dengan beberapa buah Combustion basket, mengelilingi sisi masuk (inlet) turbin. Di dalam Combustion Chamber dipasang komponenkomponen untuk proses pembakaran beserta sarana penunjangnya, diantaranya:

$$
\begin{aligned}
& \text {-Fuel Nozzle } \\
& \text {-Combustion Liner } \\
& \text {-Transition Piece } \\
& \text {-Igniter dan Flame Detektor }
\end{aligned}
$$

\section{Turbin}

Turbin Gas berfungsi untuk membangkitkan energi mekanis dari sumber energi panas yang dihasilkan pada proses pembakaran. Selanjutnya energi mekanis ini akan digunakan untuk memutar generator listrik baik melalui perantara Load Gear atau tidak, sehingga diperoleh energi listrik. Bagian-bagian utama Turbin Gas adalah:
- Sudu Tetap
- Sudu Jalan
- Saluran Gas Buang
- Saluran Udara Pendingin
- Batalan
- Auxiallary Gear 


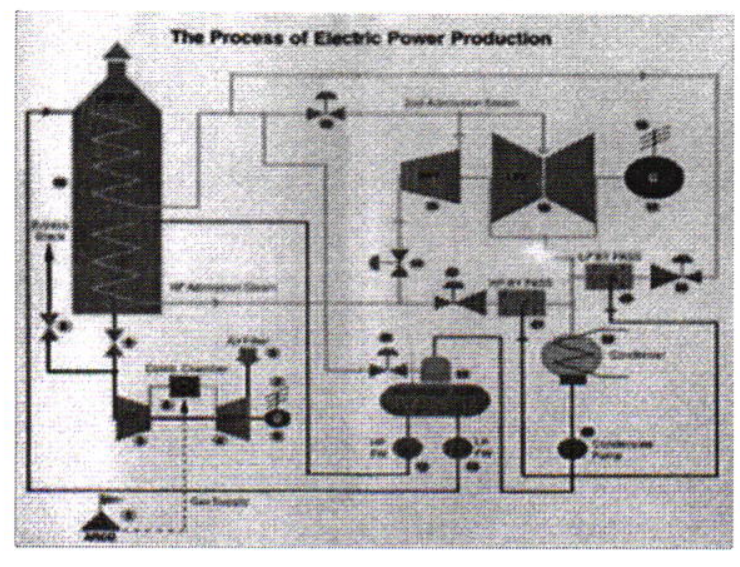

Gambar 5. Combine Cycle

Udara dikompressi di dalam kompresor dan selanjutnya udara bertekanan dialirkan ke dalam ruang bakar dan bercampur dengan bahan bakar sehingga terjadi proses pembakaran. Gas hasil pembakaran berekspansi di dalam turbin gas sehingga dihasilkan tenaga mekanik poros. Poros turbin gas dikopel dengan generator listrik sehingga dihasilkan tenaga listrik. Gas bekas dari turbin gas dialirkan kedalam Heat Recovery Steam Generator (HRSG) untuk memanaskan air menjadi uap. Setelah masuk ke HRSG uap bertekanan tinggi yang kemudian digunakan untuk memutar High Pressure Steam Turbine (HPST), kemudian HPST memutar Low Pressure Steam Turbine (LPST). Selanjutnya uap berekspansi di dalam turbin uap sehingga dihasilkan tenaga mekanik poros. Poros turbin uap dikopel dengan generator listrik sehingga dihasilkan tenaga listrik. Uap bekas dari turbin uap dikondensasikan di dalam kondensor dan dialirkan ke pompa. Dari pompa kemudian dialirkan kembali ke HRSG. Proses tersebut terus menerus berlanjut sehingga terbentuk siklus tertutup.

\section{Gambaran Umum Turbin Gas Pada PLTGU Priok}

Turbin gas pada PLTGU Priok dibangun pada tahun 1993 bersamaan dengan komponen PLTGU lainnya. Dalam hal ini PLTG (gas turbin) menjadi penghasil daya listrik dan gas sisa dari PLTG ini dimanfaatkan untuk memanaskan air dalam HRSG. Tipe turbin gas pada PLTGU Priok ini yaitu GT.13E1 yang dapat bekerja dengan beban 70-130 MW dengan bahan bakar gas, HSD (high speed diesel), atau DUAL (menggunakkan gas dan HSD) bersamaan. Pasokan udara lebih (excess air) untuk turbin gas dapat mencapai $350 \%$. Disamping untuk mendapatkan pembakaran yang sempurna, udara lebih ini digunakan untuk pendingin dan menurunkan suhu gas hasil pembakaran.

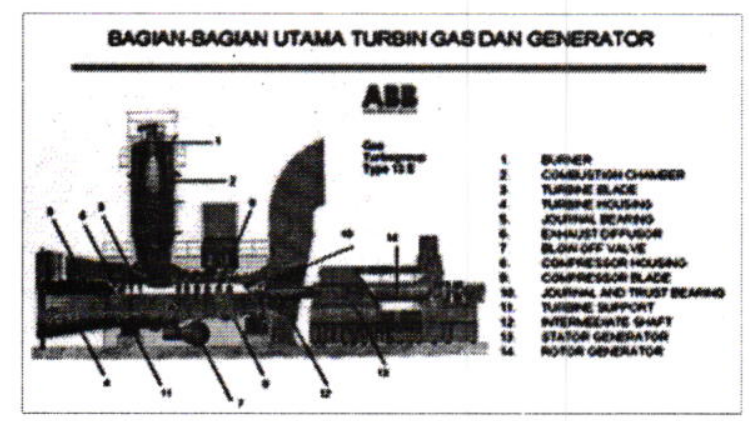

Gambar 6. GT 13-E1

\section{Spesifikasi Turbin Gas}

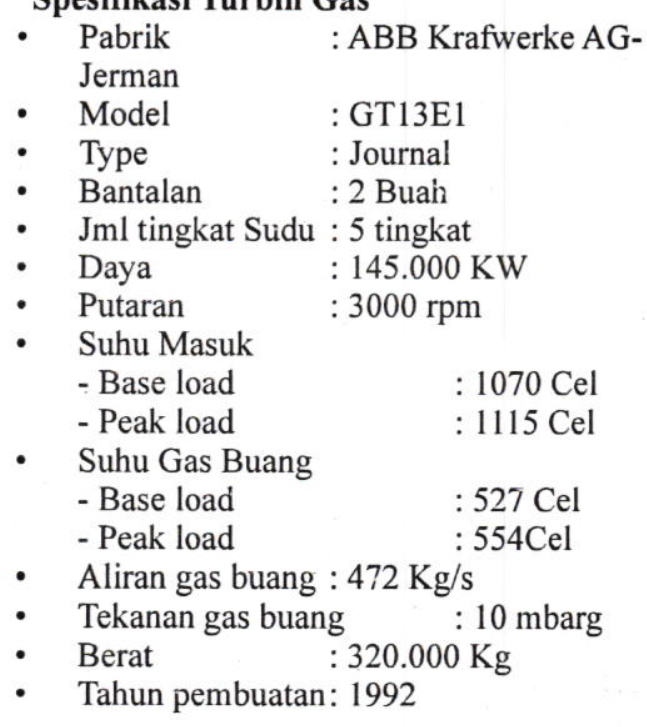

Spesifikasi Combustion Chamber (Vertical Single Burner)

- Pabrik : ABB Krafwerke AG-Jerman

- Max pressure: 16,6 Bar (pada T = 350 Cel)

- Max temp : $453 \mathrm{Cel}($ pada $P=12,4$ Bar)

- Kapasitas : $36 \mathrm{m3}$

- Berat : $40.000 \mathrm{Kg}$

- Tahun : 1992

\section{Spesifikasi Kompresor}

- Pabrik : ABB Krafwerke AG-Jerman

- Type : Axial compressor

- Jml tingkat :21

- Design air flow: $491 \mathrm{Kg} / \mathrm{s}$

- Comp ratio: 13,8

- Tahun : 1992 


\section{PEMBAHASAN}

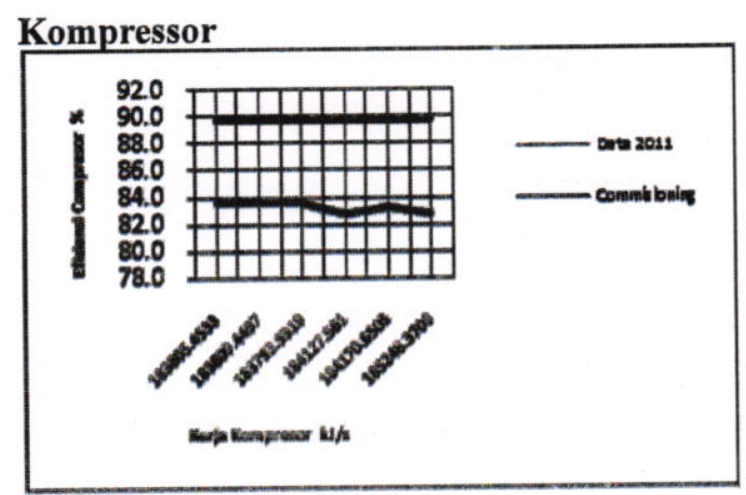

Gambar 7. Hubungan efisien terhadap kerja kompressor

Berdasarkan hasil pengujian metode tidak langsung didapat efisiensi kompresor pada tahun 2011 dengan rentang $82,7-83,5 \%$, dan rata-rata $83,13 \%$. Jika dibandingkan dengan efisiensi kompresor saat commisioning yaitu $90 \%$, maka efisiensi compressor terjadi penurunan sebesar 6-7\% (lihat Gambar 7). Dari Gambar 7 pada data 2011 juga terlihat bahwa semakin tinggi kerja kompresor maka semakin menurun nilai efisiensi kompresor. Parameter utama yang perlu diperhatikan pada kompresor adalah temperatur masuk kompresor (temperature ambient), semakin tinggi temperatur masuk kompresor maka semakin menurun nilai efisiensi kompresor. Kenaikan temperatur udara masuk kompresor ini akan menyebabkan peningkatan jam kerja kompresor dengan kata lain kerja kompresor aktual lebih tinggi dari kerja kompresor ideal. Selain itu, temperatur udara masuk kompresor menyebabkan menurunnya rasio kompresi, hal ini dapat terlihat dari $\mathrm{P} 1: \mathrm{P} 2$ saat tahun 2011 lebih rendah daripada saat commisioning. Dengan kata lain, penurunan efisiensi kompresor dapat diakibatkan oleh kualitas udara yang semakin buruk sehingga menyebabkan temperature ambient meningkat. Selain itu, adanya kontaminasi debu pada sudusudu kompresor serta letak PLTGU Priok yang sangat dekat dengan pantai, sehingga udara yang diserap oleh kompresor banyak mengandung ion Natrium dan Clorida yang akan mempercepat proses korosi pada kompresor.

\section{Ruang Bakar}

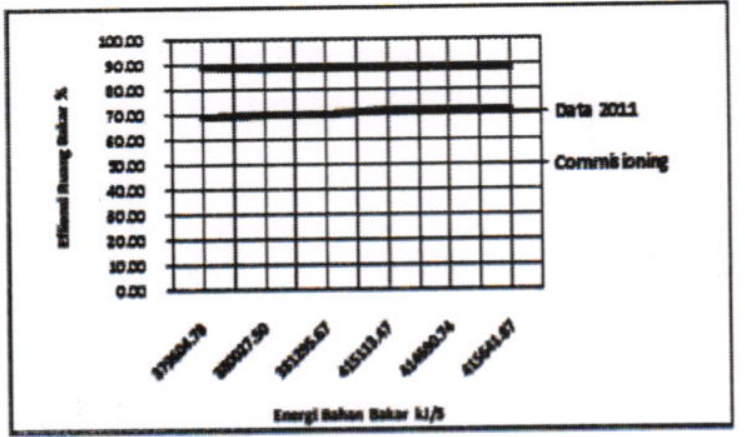

Gambar 8. Hubungan efisien ruang bakar terhadap energi bahan bakar

Dari hasil pengujian diperoleh bahwa komponen utama turbin gas yang mengalami penurunan efisiensi paling besar tahun 2011 dibandingkan dengan commisioning yaitu komponen ruang bakar yaitu sebesar 16,8-18\%. Parameter yang perlu diperhatikan pada komponen ruang bakar yaitu, kualitas bahan bakar, temperatur keluaran ruang bakar, dan temperatur masuk ruang bakar. Pada saat pengujian dan saat commisioning bahan bakar yang digunakan yaitu HSD (High Speed Diesel), kontruksi ruang bakar GT 13-E1. UBP Priok ini dapat menggunakan 2 bahan bakar yaitu HSD dan Gas alam, serta campuran (dual). Kualitas bahan bakar HSD kurang baik karena mengandung natrium dan kalsium yang akan menyebabkan korosi pada material turbin gas. Selain itu HSD memiliki rantai karbon lebih panjang dibanding Gas sehingga panas yang dihasilkan oleh HSD lebih tinggi, hal ini akan menyebabkan komponen/material ruang bakar cepat panas sehingga perawatan akan lebih sering.

Temperatur yang dihasilkan ruang bakar $\left(\mathrm{T}_{3}\right)$ jika dibandingkan dengan temperatur yang dihasilkan saat commisioning, secara tidak langsung panas yang diserap ruang bakarpun $\left(\mathrm{q}_{\mathrm{rb}}\right)$ akan mengalami penurunan. Penurunan temperatur dan panas yang diserap ruang bakar ini akan menyebabkan menurunnya efisiensi ruang bakar. Selain itu, tekanan saat proses pembakaran seharusnya dalam keadaan konstan $\mathrm{P} 2=\mathrm{P} 3$, akan tetapi karena adanya kerugian gesekan antara gas pembakaran dengan bagian ruang bakar sehingga menyebabkan penurunan tekanan keluar ruang bakar, hal ini juga yang menyebabkan menurunnya efisiensi ruang bakar. 


\section{Turbin}

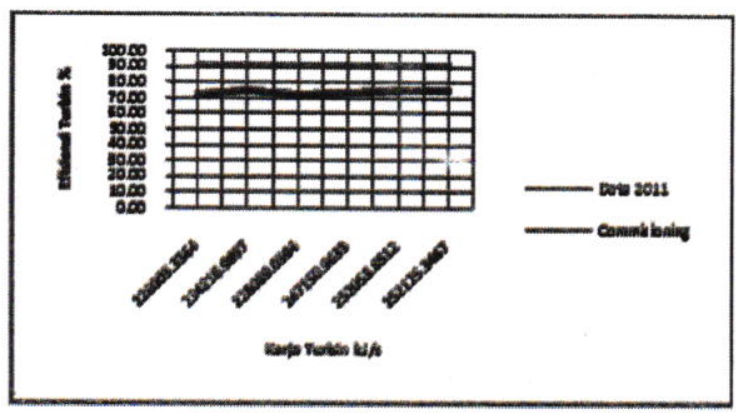

Gambar 9. Efisiensi turbin terbahap kerja turbin

Parameter yang terpenting dalam turbin yaitu, temperatur masuk turbin (temperatur keluar ruang bakar), temperatur keluaran turbin, produksi listrik yang dihasilkan. Dari tabel data hasil perhitungan terlihat bahwa temperatur yang dihasilkan turbin lebih rendah dibandingkan dengan commissioning. Rendahnya temperatur yang dihasilkan turbin dan temperatur masuk turbin, akan mengakibatkan kerja kompresor aktual lebih rendah dari kerja kompresor ideal, serta produksi listrik yang dihasilkanpun menjadi rendah. Dari data hasil perhitungan terlihat rentang selisih antara kerja turbin aktual dengan kerja turbin ideal sangat jauh, berbeda dengan data commisioning rentang selisih keduanya tidak terlalu jauh.

\section{SFC (Konsumsi spesifik bahan bakar)}

Dengan parameter SFC maka dapat terlihat seimbang atau tidaknya konsumsi bahan bakar terhadap produksi lisrik yang dihasilkan, serta efisien atau tidaknya ruang bakar.

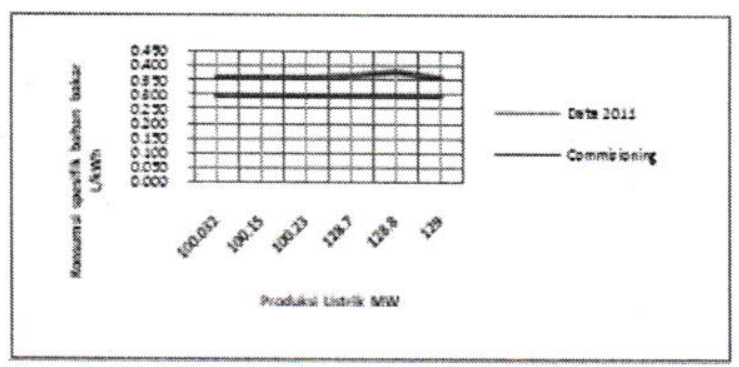

Gambar 10. Hubungan SFC terhadap produksi listrik

Dari grafik SFC diatas (Gambar 10) terlihat konsumsi spesifik bahan bakar tahun 2011 lebih besar dibandingkan data pada saat commisioning. Pada beban rendah konsumsi spesifik bahan bakar lebih tinggi ketimbang pada saat beban tinggi, hal ini terjadi karena pada saat beban rendah komposisi bahan bakar dan udara tidak sebaik pada saat beban tinggi. Dari grafik inipun terlihat pemakaian bahan bakar cukup boros, dengan kata lain bahan bakar dan produksi listrik yang dihasilkan tidak seimbang.

\section{Heat Rate}

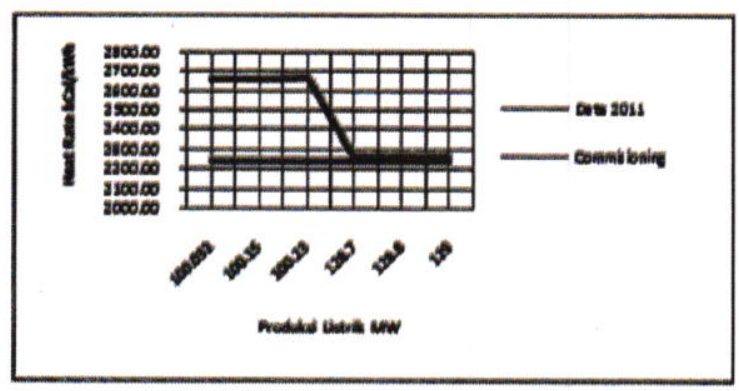

Gambar 11. Hubungan heat rate terhadap produksi listrik

Dari grafik heat rate (Gambar 11) terlihat bahwa pada saat turbin gas berada pada beban rendah, maka heat rate tinggi, lain halnya pada saat beban tinggi heat rate mendekati nilai pada saat commisioning. Dengan demikian semakin rendah nilai heat rate maka akan semakin baik untuk material komponen turbin gas.

\section{KESIMPULAN}

Dari hasil penelitian ini dapat diambil beberap kesimpulan, yaitu:

1. Pada kompressor terjadi penurunan efisiensi dibanding data commissioning yaitu sebesar $6,5-7,3 \%$. Hal ini kemungkinan diakibatkan oleh:

- Menurunnya kualitas udara yang disebabkan pemanasan global sehingga menyebabkan temperatur udara masuk kompresor (Temperature ambient) menjadi meningkat.

- Letak PLTGU Priok dekat dengan laut sehingga udara yang digunakan oleh kompresor mengandung ion natrium dan klorida yang dapat menyebabkan 
korosi pada kompresor.

- Penurunan rasio kompresi dari data hasil pengukuran, yang diakibatkan karena meningkatnya kerja kompresor.

2. Terjadi penurunan efisiensi di ruang bakar dengan sebesar 16,8-19,1\%. Hal ini disebabkan oleh:

- Adanya kerugian pada ruang bakar yaitu gesekan bahan bakar dengan bagian ruang bakar sehingga menyebabkan penurunan tekanan di dalam ruang bakar.

- Kurangnya supply udara untuk pembakaran hasil kompresi di kompresor, sehingga mengakibatkan pembakaran kurang sempurna.

- Kualitas bahan bakar yang kurang baik, HSD memiliki rantai karbon lebih panjang dari gas, sehingga rentan terjadinya pembakaran kurang sempurna lebih besar

3. Terjadi penurunan efisiensi turbin sebesar $15,9-18,18 \%$.

4. Terjadi penurunan efisiensi thermal di turbin gas sebesar $15-21 \%$.

\section{DAFTAR PUSTAKA}

"Turbin Gas".

http://www.scribd.com/doc/35705414/

Teori-Dasar-Turbin-Gas (11 Agustus

2011)

"Prinsip kerja Turbin Gas".

http://www.google.com/search.prinsip +kerja+turbin (7 Februari 2009)

"siklus brytonTurbin Gas".

http://web.me.unr.edu/me372/Spring200

1/Brayton\%20Cycle.pdf(11 Juli 2008)

Maridjo. 1995. Petunjuk Praktikm Mesin Konversi: untuk Mahasiswa Politeknik Jurusan Teknik Energi. Bandung: Pusat Pengembangan Pendidikan Politeknik

Moran, Michael J dan Howard N Saphiro. 2006. Fundamental of Engineering Thermodynamics. England: John Wiley \& Sons, Inc

Mohammad Nazri. 1996. Pembakaran turbin gas, halaman 609 :Jakarta . 